\title{
Last but not least: the ethics of the ordinary
}

\begin{abstract}
'Just a quick one doctor,' The last patient on Friday afternoon gave Mike a big smile as he beckoned her into his room. He gave a sigh of relief and returned the smile as she sat down. It was 20 past 5 , and catching the train to London to meet an old friend seemed a realistic prospect. The afternoon had run to time: one person with complex emotional needs had thankfully been followed by three non-attenders.
\end{abstract}

'It's simple really,' Mrs Barnard explained, 'I need to know which surgeon to go to for gastric banding.'

Mikes had a sinking feeling. This sounded far from a quick one. $\mathrm{He}$ suppressed his resentment, and tried to feel (or at least to look as if he were feeling), that the care of his patient was his first concern.

As he checked her records, he reflected on previous patients he had referred to NHS weight reduction programmes. Weight loss drugs were only for those who were receiving counselling and had already lost some weight: was it 3 kilograms in 6 months? To be considered for bariatric surgery might take a year after the drugs had given her orange diarrhoea. And did she fit the NICE criteria? What were they? 'Tell me a bit more ...' he heard himself saying.

He could see that Mrs Barnard was overweight, but he wouldn't have thought her obese: two fatter people had been in that afternoon to discuss their diabetes and knee pains. Weight loss had not been on their agendas.

'I've been trying to lose weight for nearly 2 years. I've been to the local weight-loss club, l've taken Reductil ${ }^{\circledast}$...'

Mike nodded and scrolled through the notes. Drawing a mental blank he surreptitiously looked up 'Reductil'. A drug which promoted satiety:

'After the Reductil I actually put on weight,' Mrs Barnard continued.

The graph confirmed this: a period of weight loss, then gradually increasing figures.
'It started after the birth of my first child.' 'I was a professional gymnast ...'. She began to blink away tears.

This must have been a dramatic change in body shape; Mike imagined how distressing it must be. In a brief empathic moment, he remembered that he was not exactly an advertisement for fitness. Nevertheless, he marshalled words to convey waiting, regional clinics, and more diets and medications.

'My husband and I have discussed this. We'd like to go private, and my insurance company said I should see you for a referral to someone reputable in the area... We've heard horror stories about people going abroad and having botched surgery.'

'Is the insurance paying?' A ray of hope as the clouds parted ...

'No but we thought we'd try them first. Doctor, l've been trying to lose weight for 2 years and I'm even fatter. I'm not getting younger and we don't want to wait any more.' Mike asked Mrs Barnard to stand on the scales. One hundred and two kilograms: a BMI of 32 .

'My husband and I really want to do this - is there someone local? If not we can go to London.'

Mike rang the local private hospital. Yes they had a weight reduction surgery clinic, run by a senior surgeon from the local NHS hospital who did gastric banding. The nurse in charge of the clinic said they would be happy to receive a referral 'No surprise there,' thought Mike. Mrs Barnard seemed relieved. She knew the hospital - friends had been treated there, and she had also heard of the surgeon. She left, happy, with the promise of a typed referral.

At 10 to 6, Mike jumped in the taxi, in time for his train.

Although this story is fictitious, every GP will have had experiences like this; a patient with a complex problem just when you want to get away early, patients who want things which seem reasonable but are not available on the NHS; or wanting private referrals for procedures which, for good reasons, are not available on the NHS.

The story raises several ethical questions:

- How does the doctor reconcile his legitimate plans for an evening out with the needs of his patient?

- Should he ask the patient to return later, when he has had time to explore the options?

- Is it right to treat private and NHS referrals differently?

- Should he spend longer with this patient, desperate about her weight, than with others with greater problems but less concern?

- If you stop eating you lose weight: when is surgery appropriate for lifestyle related diseases?

- Whose agenda dominated this consultation? Does it matter that the husband is referred to in deciding on bariatric surgery?

But if you read medical ethical journals, or scan the ethics section of your local medical bookshop, you will not find much discussion of questions like that. Popular and much academic debate focuses on 'glamorous' problems - embryonic stem-cell research and assisted suicide; important issues, but affecting far fewer people than these sorts of questions the 'Ethics of the Ordinary'. What debate there is lies scattered among journals and books; there is nowhere to find it easily, no forum to discuss questions like this, little to give to GP registrars to help them think clearly and act virtuously when they face such situations.

A group of GPs interested in ethics want to change this. The Royal College of General Practitioners and Society of Medicine have joined forces to mount a symposium on the ethical problems of primary care, with workshops, poster displays and keynote addresses. These include Iona Heath from the GP 


\section{Book review}

perspective and Deborah Bowman, a well known ethicist interested in primary care. Our aim is to bring together all those who are interested in the values as well as the science of general practice, whether as clinicians, managers, teachers or researchers. Which means pretty well all of us.

For further details and to register interest for the meeting, email sophie.baettig@rsm.ac.uk.

\section{Andrew Papanikitas and Peter Toon}

\section{WHY US? \\ HOW SCIENCE REDISCOVERED THE MYSTERY OF OURSELVES JAMES LE FANU \\ Harper Press, 2009 \\ HB, 303pp, £18.99, 9780007120277}

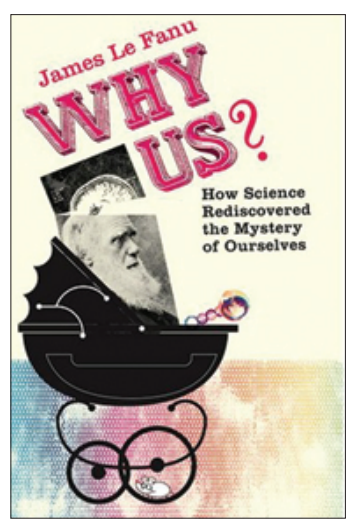

James Le Fanu's new book sets out to argue two things. We can't, he says, simply be the chance products of a materialist evolutionary process; and, however much we may learn about ourselves as machines, we could never learn enough to account for the aweinspiring complexity of our nature.

The argument centres on essentially two phenomena. One is the discrepancy between our ever more detailed knowledge of the human brain and the failure of this knowledge to tell us anything much about the mind. It's true that, as he says, the complexity of experience cannot be reduced to a few patches of neural tissue lighting up on a scan. But nonetheless, such patches do tell us at least something - pretty crude though it may be - about the mind of the person whose brain we are inspecting. Where I agree, is that it still tells us nothing whatever about what it is to have a mind at all. To expect amassing scientific information ever to do so is a basic philosophical error, a category mistake.

The other phenomenon on which Le Fanu focuses, and to me this is both the more interesting and the more controversial part of his argument, is the apparent 'decoding' of the human genome. This mighty project, which came in ahead of schedule, and was confidently expected by many to be the key that unlocked the secrets that would enable us to treat and even eliminate disease, has been a resounding disappointment. The clinical rewards have been so far meagre, to say the least. But Le Fanu goes further. The information in the DNA sequences is simply not enough - never could be enough - to explain the complex structure and functioning of the pieces of work it codes for: and what a piece of work is man! In arguing this, he adduces information that will surely prove fascinating to many readers.

We have 26000 genes. But a blind, millimetre-long roundworm with only 959 cells in total already has over 19000. Then there is the sheer extent of the problem of 'junk' DNA. The human genome contains so much data that, it has been calculated, it would fill 43 volumes of Webster's International Dictionary. But it is as if no less than 42 of them contained no genetic information at all, consisting of tens of thousands of repetitions of just one letter of the genetic code. What even the remaining bits do, it seems, is hard to predict. The same genetic disease can be caused by different mutations in several different genes, and conversely, several different diseases can stem from mutations in a single gene. The selfsame gene may be involved in the production of the eyes, nose, brain, pituitary, gut or pancreas, but along with thousands of other genes, and depending on precisely which other genes are involved.

It seems that 'context is all'. Philip Gell, Professor of Genetics at Birmingham, writes: 'The heart of the problem lies in the fact that we are dealing not with a chain of causation but with a network', ${ }^{1}$ a bit like a spider's web in which a perturbation at any point of the web changes the tension of every fibre in it. And this does have implications for the classical theory of natural selection, since, as Le Fanu says, given this 